American Journal of Biochemistry and Biotechnology 6 (2): 141-147, 2010

ISSN 1553-3468

(C) 2010 Science Publications

\title{
Effect of Camel's Milk on Cisplatin-Induced Nephrotoxicity in Swiss Albino Mice
}

\author{
Mohamed E.M. Afifi \\ Department of Medical Laboratories, (Clinical Biochemistry), \\ Community Collage, King Khalid University, Bisha, Saudi Arabia \\ Department of Biochemistry, Faculty of Veterinary Medicine, \\ Zagzig University, Zagzig, Egypt
}

\begin{abstract}
Problem statement: Nephrotoxicity is a major complication and a dose limiting factor for cisplatin therapy. Cisplatin mediated nephrotoxicity is remarkably documented by reactive oxygen species. Camel's milk has good nutritive value, antigenotoxic and anticytotoxic effects. The aim of the present study was to assess the protective effect of camel's milk against Cisplatin-induced renal oxidative stress in mice. Approach: Forty mal Swiss albino mice were randomly divided into four groups $(\mathrm{n}=10)$. Group I, control group. Group II was received cisplatin $\left(12 \mathrm{mg} \mathrm{kg}^{-1}\right)$ for 5 alternate days. Group III was received camel's milk $\left(33 \mathrm{~mL} \mathrm{~kg}^{-1}\right)$ for consecutive 30 days. Group IV was received camel's milk (33 $\mathrm{mL} \mathrm{kg}^{-1}$ ) for consecutive 30 days before administration of Cisplatin. Results: Cisplatin-induced oxidative stress was indicated by increased level of tissue Malondialdehyde (MDA), serum creatinine and urea, decreased the concentration of reduced Glutathione (GSH), Vitamin C (Vit. C) and Vitamin E (Vit. E) and decreased both activities and gene expression of Superoxid Dismutase (SOD), Catalase (CAT), Glutathione Raductase (GR) and Glutathione Peroxidase (GPx). Camel's milk reduced these biochemical changes and counteracted the deleterious effects of cisplatin Conclusion: The present study demonstrated the renoprotective potential of camel's milk against cisplatin-induced oxidative stress and renal dysfunction in mice. Hence, camel's milk has a potential to be used as therapeutic adjuvant in cisplatin nephrotoxicity.
\end{abstract}

Key words: Camel's milk, cisplatin, nephrotoxicity

\section{INTRODUCTION}

Cisplatin is a potent antitumor drug. Cisplatinbased combination chemotherapy regimens are currently used as front-line therapy in the treatment of testicular cancer, ovarian germ cell tumors, epithelial ovarian cancer, head and neck cancer, advanced cervical cancer, bladder cancer, mesothelioma, endometrial cancer, non-small cell lung cancer, malignant melanoma, carcinoids, penile cancer, adrenocorticol carcinoma. The therapeutic effects of cisplatin are significantly improved by dose escalation. However, high-dose therapy with cisplatin is limited by its cumulative nephrotoxicity and neurotoxicity (Noori and Mahboobc, 2010).

It is well known that mitochondria continuously produce Reactive Oxygen Metabolites (ROM) such as superoxide. Mitochondria also continuously scavenge ROM via the action of antioxidant enzymes such as superoxide dismutase, glutathione peroxidase, catalase and glutathione Stransferase. Cisplatin is known to accumulate in mitochondria of renal epithelial cells (Santos et al., 2008). Several investigators have demonstrated that cisplatin induces ROS in renal epithelial cells primarily by decreasing the activity of antioxidant enzymes and by depleting intracellular concentrations of GSH (Huang et al., 2001). A large number of studies have now accumulated documenting the beneficial effects of a variety of antioxidants in cisplatininduced nephrotoxicity. Agents such as superoxide dismutase, dimethylthiourea and GSH have been shown to reduce the degree of renal failure and tubular cell damage when administered simultaneously with cisplatin in rats (Tsuji et al., 2009).

Camel's milk is different from other ruminant milk; having low cholesterol, low sugar, high minerals (sodium, potassium, iron, copper, zinc and magnesium), high vitamin $\mathrm{C}, \mathrm{B} 2, \mathrm{~A}$ and $\mathrm{E}$, low protein and high concentrations of insulin. It has no allergic properties and it can be consumed by lactase deficient persons and those with week immune systems. The milk is considered to have medicinal properties. In Sahara, 
fresh butter is often used as a base for medicines. The products developed also include cosmetics or pharmaceuticals. A series of metabolic and autoimmune diseases are successfully being treated with camel's milk (Al-Hashem, 2009). In India, camel's milk is used therapeutically against dropsy, jaundice, problems of the spleen, tuberculosis, asthma, anemia, piles and diabetes (Cai et al., 2001). Beneficial role of raw camel's milk in chronic pulmonary tuberculosis patients has been observed (Mal et al., 2001). In repeated trials, it was observed that there was $30-35 \%$ reduction in daily doses of insulin in patients of type 1 diabetes receiving raw camel's milk (Agrawal et al., 2002).

In our survey, we didn't find any study dealt with the therapeutic effect of camel's milk against the bad effect of cisplatin on kidney, therefore in this study, we tested the effects of oral administration Camel's milk in mice by examining its possible protective effects against cisplatin nephrotoxicity.

\section{MATERIALS AND METHODS}

Camel's milk samples: Milk samples were collected early morning daily from Camel's farm in Bilbis area (South to Cairo). Milk was collected from camels by hand milking as normally practiced by the farmers. The samples were collected in sterile screw bottles kept in cool boxes until transported to the laboratory.

Chemicals: Cis-Diamminedichloroplatinum-II Cisplatin (Cis-DDP) was purchased in the form of a solution dissolved in distilled water (CAs No. 781520-03) under the trade name cisplatinum (EBEWE Pharma, Austria). It was used in a dose of $12 \mathrm{mg} \mathrm{kg}^{-1}$ b.w. i.p. for 5 alternate days (Cepeda et al., 2007).

Experimental design: Male Swiss albino mice (20$25 \mathrm{~g}$ ), were supplied by laboratory animal farm, Helwan, Egypt. The local committee approved the design of the experiments and the protocol conforms to the guidelines of the National Institutes of Health (NIH). The mice were housed in standard plastic cages $(10 \mathrm{mice} / \mathrm{cage})$ at an environmentally controlled room (constant temperature $25-27^{\circ} \mathrm{C}$, with $12 \mathrm{~h}$ light/dark cycle) before and during the experiments. The mice were fed a stock diet containing $50 \%$ wheat, $21 \%$ corn, $20 \%$ soybean, $8 \%$ concentrated proteins and $1 \%$ a mixture of salts, vitamins and dicalcium phosphate. Water was supplied ad libitum. Four groups of mice each of 10 mice were used; all treatments were given by cavage needle for 30 days, they were treated as follows:
Group I: Control group

Group II: Received cisplatin i.p. (12 $\mathrm{mg} \mathrm{kg}^{-1}$ b.w.) for 5 alternate days

Group III: Received camel's milk (33 mL kg-1 b.w. orally) for 30 days

Group IV: Received camel's milk (33 mL kg-1 b.w. orally) for 30 days before administration of Cisplatin (12 $\mathrm{mg} \mathrm{kg}^{-1}$ b.w.) for 5 alternate days

Collection of blood serum: At the end of experiment, the animals were subjected to over night fasting and then were scarified by cervical dislocation and blood samples were collected directly into plain tubes and then were centrifuged at $3000 \mathrm{rpm}$ for $10 \mathrm{~min}$ to obtain serum for measuring the indices of nephrotoxicity.

Preparation of kidney homogenate: The kidney was quickly removed, washed in icecold, isotonic saline and blotted on ash-free filter paper, The tissues were then homogenized in $0.1 \mathrm{M}$ Tris- $\mathrm{HCl}$ buffer, $\mathrm{pH} 7.4$ using a Potter-Elvejham homogenizer at $4^{\circ} \mathrm{C}$ with a diluting factor of 4, the crude tissue homogenate was then centrifuged at a speed of $9000 \mathrm{rpm}$ for $15 \mathrm{~min}$ in cold centrifuge (Al-Hashem, 2009), the supernatant was kept at $-20^{\circ} \mathrm{C}$ for estimation of TBARS, reduced Glutathione (GSH), vitamin C, vitamin E Superoxide Dismutase (SOD), Catalase (CAT), Glutathione Peroxidase (GPx) and Glutathione Reductase (GR) activities.

Preparation of kidney tissue for gene expression analysis: Small parts of kidney were dissected rapidly, post-mortem and kept in liquid nitrogen until used for determination of GPx, CuZnSOD and CAT gene expression.

Biochemical serum parameters analyses: Serum creatinine and urea concentrations were measured using commercial available Assay Kit (Spinreact REF 1001111 and 1001332 respectively), according to manufacture instruction.

\section{Estimation of lipid peroxidation and oxidative stress} parameters in tissue homogenate:

Estimation of TBARS: The concentration of Thiobarbituric Acid Reactive Substances (TBARS) in the kidney homogenate was determined by using commercial available Assay Kit (Northwest Life Science Specialties, NWK-MDA01), according to manufacture instruction.

Estimation of reduced glutathione: The GSH content of the kidney homogenate was measured at $412 \mathrm{~nm}$ using commercial available Assay Kit (Northwest Life Science Specialties, NWK-GSH01), according to manufacture instruction. 
Estimation of catalase activity: Catalase activity was assayed using commercial available Catalase Activity Assay Kit (Northwest Life Science Specialties, NWKCAT01), according to manufacture instruction.

Estimation of SOD activity: The activity of SOD in kidney was assayed using commercial available SOD Activity Assay Kit (Northwest Life Science Specialties, NWK-SOD02), according to manufacture instruction.

Estimation of GPx activity: The activity of GPX in kidney homogenate was assayed using commercial available GPx Activity Assay Kit (Northwest Life Science Specialties, NWK-GPX01), according to manufacture instruction.

Estimation of GR activity: The activity of GR in kidney homogenate was assayed using commercial available GR Activity Assay Kit (Northwest Life Science Specialties, NWK-GR01), according to manufacture instruction.

Estimation of vitamin $\mathbf{C}$ concentration: The concentration of vitamin $\mathrm{C}$ in the kidney homogenate were determined by the method of Kyaw (1978).

Estimation of vitamin $\mathbf{E}$ concentration: The concentration of vitamin $\mathrm{E}$ in the kidney homogenate were determined by the method of Baker and Frank (1968).

\section{Estimation of kidney GPx, CuZnSOD and CAT gene expression:}

Total RNA preparation: Kidney samples were pulverized in liquid nitrogen and total RNA was prepared from the frozen powder using the E.Z.N.A ${ }^{\mathrm{TM}}$.spin column RNA extraction kit (Omega Bio-Tech, Cat NO R6834-01, Canada) following the manufacturer instructions.

The amount of extracted RNA was quantified by measuring the absorbance at $260 \mathrm{~nm}$. The purity of RNA was checked by the ratio between the absorbance values at 260 and $280 \mathrm{~nm}$ and ranged between 1.8 and 2.1, demonstrating the high quality of the RNA. This was confirmed in $52(16 \%)$ randomly selected samples by electrophoresis on $1.5 \%$ agarose gel containing ethidium bromide.

RT-PCR: One-half microgram of total RNA was denatured for $10 \mathrm{~min}$ at $72^{\circ} \mathrm{C}$ and was reversed transcribed to cDNA by incubating with $10 \mu \mathrm{L}$ RT reaction mixture containing: $50 \mathrm{mM}$ Tris- $\mathrm{HCl}, 75 \mathrm{mM}$ $\mathrm{KCl}, 3 \mathrm{mM} \mathrm{MgCl}, 10 \mathrm{mM}$ dithiothreitol, $0.5 \mathrm{mM}$ of each dNTP, $62.5 \mathrm{mU}$ RNA guard, $50 \mathrm{ng}$ random hexamers and $100 \mathrm{U}$ Superscript II reverse transcriptase. Incubation was performed at $42^{\circ} \mathrm{C}$ for 60 min, heated to $95^{\circ} \mathrm{C}$ for $5 \mathrm{~min}$ and then quickly chilled on ice.

The PCR reaction mixture contained $2 \mu \mathrm{L}$ cDNA, $0.2 \mathrm{mM}$ of each dNTP and the Taq polymerase buffer, which contained $10 \mathrm{mM}$ Tris- $\mathrm{HCl} \mathrm{pH} 8.3,50 \mathrm{mM} \mathrm{KCl}$, $1.5 \mathrm{mM} \mathrm{MgCl}_{2}, 7.5 \mathrm{pM}$ of each primer and $1.5 \mathrm{U}$ of Taq polymerase.

PCR conditions were a denaturation step at $95^{\circ} \mathrm{C}$ for $2 \mathrm{~min}$ followed by 28 cycles of $95^{\circ} \mathrm{C}, 1 \mathrm{~min} ; 55^{\circ} \mathrm{C}$, $1 \mathrm{~min} ; 72 \mathrm{C}, 1 \mathrm{~min}$. PCR were performed with a 2720 thermocycler (Applied Biosystems, USA). PCR products were analyzed on a $2 \%$ agarose gel in $90 \mathrm{mM}$ Tris-borate, $2 \mathrm{mM}$ EDTA Buffer (TBE), pH 8 and visualized by staining with ethidium bromide and UV transillumination, for quantitative evaluation, absolute Optical Densities (OD) of RT-PCR signals were obtained by densitometric scanning using an image analysis system (1-D Manager; TDI Ltd.). The values for the specific targets were normalized according to those of TBP to express arbitrary units of relative abundance of the specific messages (i.e., relative expression).

Primers Primer design was optimized for Polymerase Chain Reaction (PCR) with EugeneTM version 2.2 (Daniben Systems, Cincinnati, OH) using the following restrictions and listed in Table 1.

Statistics: All data were presented as means \pm SD. One way ANOVA and Duncan's test were used for comparisons among groups. Significant difference was indicated when the p-value was $<0.05$.

Table 1: Sequences of primers

\begin{tabular}{llll}
\hline Gene & & Oligonucleotide sequences & Predicted cDNA size (bp) \\
\hline GPx $^{* *}$ & Upstream & 5'-ATGGCAACTGTTCCTGAACTCAACT-3' & 197 \\
& Downstream & 5'-CAGGACAGGTATAGATTCTTTCCTTT-3' & 22 \\
& Upstream & 5'-GTCCGATTCTCCACAGTCGC-3' & \\
CuZnSOD* & Downstream & 5'-CGCTGAACAAGAAAGTAACCTG-3' & \\
& Upstream & 5'-ATGGGGACAATACACAAGGC-3' & 225 \\
ß-actin* & Downstream & 5'-TCATCTTGTTTCTCGTGGAC-3' & 260 \\
& Upstream & 5'-TCACTATCGGCAATGTGCGG-3' & \\
\hline
\end{tabular}

*: Oligonucleotide primer sequences from (Xu et al., 2000); **: Oligonucleotide primer sequences from (Jones et al., 1995) 


\section{RESULTS}

The data represented in Table 2, were showed that the concentration of serum creatinine and urea significantly increased in cisplatin group in treatment with camel's milk they are returned to the normal level. The concentration of Vit. E, Vit. C and GSH were decreased in cisplatin group, by administration of camel's milk they increased significantly when compared with cisplatin group. In contrast the Mlaondialdehyd (MDA) concentration was increased in cisplatin group but in treatment with camel's milk it increased significantly when compared with group Cisplatin treated group.

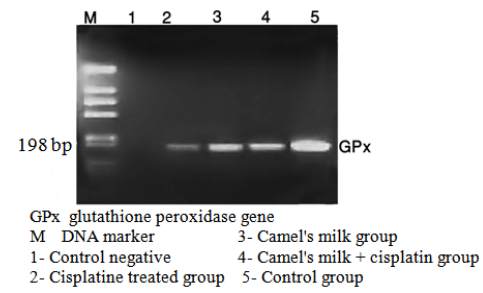

Fig. 1: Representative ethidium bromide-stained gel electrophoresis of glutathione peroxidase gene expression

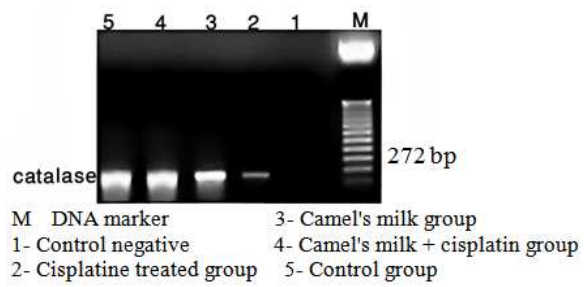

Fig. 2: Representative ethidium bromide-stained gel electrophoresis of catalase gene expression
Table 3, represents renal activities and gene expression of antioxidant enzymes as CAT, SOD, GPx and GR in cisplatin and calm's milk treated mice. The activities and gene expression of these enzymes were significantly decreased in kidney of cisplatin treated mice. On treatment with calm's milk, the decreased gene expression of these enzymes were brought back to near normal (Fig. 1-4), the activities of GR, GPx and SOD were increased significantly in camel milk treated group, but the activity of catalase enzyme was increased non significantly when compared with cisplatin group.

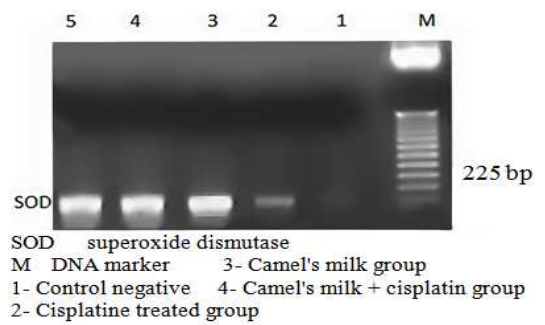

Fig. 3: Representative ethidium bromide-stained gel electrophoresis of SOD gene expression

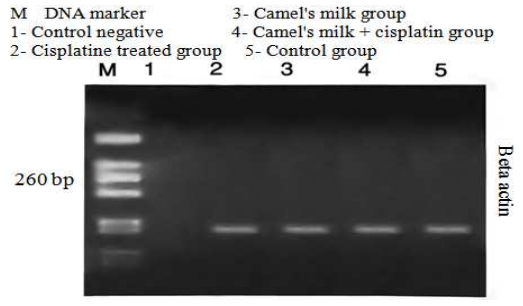

Fig. 4: Representative ethidium bromide-stained gel electrophoresis of $\beta$ actin gene expression

Table 2: Effect of cisplatein and camel's milk on serum creatinine, urea and vitamin E, vitamin C, GSH and MDA in kidney homogenate of Albino mice

\begin{tabular}{|c|c|c|c|c|}
\hline Parameter & Group I & Group II & Group III & Group IV \\
\hline Serum creatinine $\left(\mathrm{mg} \mathrm{dL}^{-1}\right)$ & $0.96 \pm 0.06$ & $2.97 \pm 0.2^{\mathrm{a}}$ & $1.1 \pm 0.08^{\mathrm{b}}$ & $1.03 \pm 0.1^{\mathrm{b}}$ \\
\hline Serum urea $\left(\mathrm{mg} \mathrm{dL}^{-1}\right)$ & $60.00 \pm 2.2$ & $89.50 \pm 10.4^{\mathrm{a}}$ & $58.0 \pm 3.4^{\mathrm{b}}$ & $60.00 \pm 1.8^{\mathrm{b}}$ \\
\hline Vitamin $\mathrm{E}$ ( $\mathrm{mg} \mathrm{L}^{-1}$ homogenate) & $624.90 \pm 73$ & $214.70 \pm 50^{\mathrm{a}}$ & $1681.5 \pm 243^{\mathrm{ab}}$ & $465.00 \pm 78.9^{\mathrm{c}}$ \\
\hline Vitamin $\mathrm{C}\left(\mathrm{mg} \mathrm{mL}^{-1}\right.$ homogenate & $25.00 \pm 5.3$ & $12.80 \pm 5.5^{\mathrm{a}}$ & $37.6 \pm 5.2^{\mathrm{ab}}$ & $24.90 \pm 6^{\mathrm{bc}}$ \\
\hline $\mathrm{GSH}\left(\mu \mathrm{M} \mathrm{g}^{-1}\right.$ tissue $)$ & $69.80 \pm 8.8$ & $27.80 \pm 3^{\mathrm{a}}$ & $83.8 \pm 18^{\mathrm{b}}$ & $51.70 \pm 2.6^{\mathrm{abc}}$ \\
\hline $\operatorname{MDA}\left(\mu \mathrm{Mg}^{-1}\right.$ tissue $)$ & $1.02 \pm 0.14$ & $3.70 \pm 0.3^{\mathrm{a}}$ & $0.9 \pm 0.2^{\mathrm{b}}$ & $1.30 \pm 0.3^{\mathrm{bc}}$ \\
\hline
\end{tabular}

All values were expressed as mean \pm SD $(n=10)$. Statistical significance between means was performed using one-way ANOVA followed by Duncan's test; ${ }^{a}$ : significant $(\mathrm{p}<0.05)$ as compared with control group (group 1); ${ }^{\text {b}}$ : significant $(\mathrm{p}<0.05)$ as compared with cisplatin group $(2)$; ${ }^{\text {: }}$ : significant $(\mathrm{p}<0.05)$ as compared with camel's milk treated group (group III); GSH: Reduced glutathione; MDA: Malondialdehyde

Table 3: Effect of cisplatein and camel's milk on antioxidant enzymes activities and gene expression in kidney homogenate of Albino mice

\begin{tabular}{|c|c|c|c|c|}
\hline Parameter & Group I & Group II & Group III & Group IV \\
\hline Serum creatinine $\left(\mathrm{mg} \mathrm{dL}^{-1}\right)$ & $0.96 \pm 0.06$ & $2.97 \pm 0.2^{\mathrm{a}}$ & $1.1 \pm 0.08^{\mathrm{b}}$ & $1.03 \pm 0.1^{\mathrm{b}}$ \\
\hline Serum urea $\left(\mathrm{mg} \mathrm{dL}^{-\mathrm{T}}\right)$ & $60.00 \pm 2.2$ & $89.50 \pm 10.4^{\mathrm{a}}$ & $58.0 \pm 3.4^{\mathrm{b}}$ & $60.00 \pm 1.8^{\mathrm{b}}$ \\
\hline Vitamin $\mathrm{E}\left(\mathrm{mg} \mathrm{L}^{-1}\right.$ homogenate) & $624.90 \pm 73$ & $214.70 \pm 50^{\mathrm{a}}$ & $1681.5 \pm 243^{\mathrm{ab}}$ & $465.00 \pm 78.9^{c}$ \\
\hline Vitamin $\mathrm{C}\left(\mathrm{mg} \mathrm{mL}^{-1}\right.$ homogenate & $25.00 \pm 5.3$ & $12.80 \pm 5.5^{\mathrm{a}}$ & $37.6 \pm 5.2^{\mathrm{ab}}$ & $24.90 \pm 6^{\mathrm{bc}}$ \\
\hline GSH $\left(\mu \mathrm{M} \mathrm{g}^{-1}\right.$ tissue $)$ & $69.80 \pm 8.8$ & $27.80 \pm 3^{\mathrm{a}}$ & $83.8 \pm 18^{\mathrm{b}}$ & $51.70 \pm 2.6^{\mathrm{abc}}$ \\
\hline $\operatorname{MDA}\left(\mu \mathrm{Mg}^{-1}\right.$ tissue $)$ & $1.02 \pm 0.14$ & $3.70 \pm 0.3^{\mathrm{a}}$ & $0.9 \pm 0.2^{\mathrm{b}}$ & $1.30 \pm 0.3^{\mathrm{bc}}$ \\
\hline
\end{tabular}




\section{DISCUSSION}

In this study, our results demonstrated that treatment with cisplatin induced biochemical signs of nephrotoxicity manifested by increased serum creatinine and urea levels. With increased lipid peroxides (MDA) and depletion of antioxidants as GSH, Vit. E and Vit. C and inhibition of SOD, CAT, GPx and GR activities and gene expression.

The increased serum creatinine and urea levels may be due to the decreased glumerular filtration rat or may be secondary to increased the Reactive Oxygen Species (ROS). Noori and Mahboobc (2010) reported that administration of cispaltin to rats caused a reduction in glomerular filtration rate, which correlated with increased creatinine and urea in plasma. The alterations in glomerular function in cisplatin treated rats may also be secondary to Reactive Oxygen Species (ROS) (Somani et al., 2000) which induce mesangial cells contraction, altering the filtration surface area and modifying the ultrafiltration coefficient factors that decrease the glomerular filtration rate (Aydogan et al., 2008).

The increased ROS attack the cell membrane lipids leads to increased tissue lipid peroxide, manifested by increased MDA. Over accumulation of lipid peroxide in tissue cause over consumption and depletion of Vitamin $\mathrm{E}$, main fat soluble antioxidant, GSH, Vitamin C and inhibition of the main antioxidant enzymes.

GSH is one of the essential compounds for maintaining cell integrity because of its reducing properties and participation in the cell metabolism. The depletion in the renal GSH level has been observed in rats in response to oxidative stress caused by Cisplatin treatment (Silva et al., 2001). It has been suggested that cisplatin is able to generate reactive oxygen species and that is also inhibits the activity of antioxidant enzymes in renal tissue such as CAT, SOD, GPx (Noori and Mahboobc, 2010).

Oxidative stress injury is actively involved in the pathogenesis of cisplatin-induced acute kidney injury. Reactive Oxygen Species (ROS) directly act on cell components, including lipids, which increase free radical production and decrease antioxidant production. These free radicals damage the lipid components of the cell membrane by peroxidation and denature proteins, which lead to enzymatic inactivation. Antioxidant enzymes are inhibited by cisplatin and renal activities of superoxide dismutase, glutathione peroxidase and catalase are significantly decreased (Yao et al., 2007).

It has been reported that administration of cisplatin to normal rats resulted in depletion of GSH and subsequent potentiation of lipid peroxidation in kidney cortical slices (Lalila et al., 2001).
Cisplatin has been thought to bind to the renal base transport system. Cisplatin induces hypomagnesemia through its renal toxicity possibly by a direct injury to mechanisms of magnesium reabsorption in the ascending limb of the loop of Henle as well as the distal tubule. Cisplatin preferentially accumulates in cells of the S3 segment of the renal proximal tubules and is toxified to form a reactive metabolite intracellularly by hydration. The primary symptoms of cisplatin nephrotoxicity are inhibition of protein synthesis and intracellular GSH and protein-SH depletion, resulting in lipid peroxidation and mitochondrial damage. GSH and protein-SH form the major cellular anti-oxidant defense systems, which control lipid peroxidation. From these pathomechanisms of cisplatin nephrotoxicity, it is clear that the nephrotoxicity of cisplatin involves reactive radicals. Thus the reasonable cellular-protective agents against cisplatin toxicity may have at least some antioxidant properties to prevent GSH depletion and/or scavenge the intracellular reactive oxygen species (Joy and Nair, 2008).

Camel's milk pretreatment caused a recovery of kidney damage induced by cisplatin. This was observed by significant restoration of serum creatinine and urea. As well as decreased of MDA and increased of GSH, Vitamin E, Vitamin C and activation of SOD, CAT, GPx and GR as will as increase of SOD, CAT and GPx gene expression.

The protective effect of Camel's milk against Cisplatin-induced toxicity, oxidative stress and tissue damage in this study could be attributed to its antioxidant content. It has been reported that camel's milk contain high levels of Vitamins C, A, B2 and E and very rich in magnesium and other trace elements (Al-Hashem, 2009). These vitamins are antioxidants found to be useful in preventing the tissues injury caused by toxic agent.

Magnesium protects cells from heavy metals such as aluminum, mercury, lead, cadmium, beryllium and nickel, which explains why re-mineralization is so essential for heavy metal detoxification and chelating. Magnesium Deficiency (MgD) has been associated with production of reactive oxygen species (Martin et al., 2003). Magnesium protects the cell against oxyradical damage and assists in the absorption and metabolism of $\mathrm{B}$ vitamins, vitamin $\mathrm{C}$ and $\mathrm{E}$, which are antioxidants important in cell protection. Recent evidence suggests that vitamin $\mathrm{E}$ enhances glutathione levels and may play a protective role in magnesium deficiency-induced cardiac lesions (Barbagallo, 1999). Also it has been reported that magnesium is very essential for biosynthesis of glutathione, because the enzyme Glutathione synthetase requires $\gamma$-glutamyl cysteine, 
glycine, ATP and magnesium ions to form glutathione (Virginia et al., 1971).

Also, Camel's milk is rich in Zinc (Zn) (AlHashem, 2009). Zinc is a trace element essential for living organisms. More then 300 enzymes require $\mathrm{Zn}$ for their activity. It also plays an important role in the DNA replication, transcription and protein synthesis, influencing cell division and differentiation (Frederickson, 1989). It has been noted that $\mathrm{Zn}$ has a relationship with many enzymes in the body and can prevent cell damage through activation of the antioxidant system (Ozdemir and Inanc, 2005; Santos et al., 2008). Zinc is an essential component of the oxidant defense system and functions at many levels (Sato and Bremner, 1993). One study has shown that $\mathrm{Zn}$ deficiency in the diet paves the way for cell damage in the rat testis (Cai et al., 2001). Furthermore, Zn deficiency increases lipid peroxidation in various rat tissues, whereas the $\mathrm{Zn}$ supplementation corrects the impairment (Ozdemir and Inanc, 2005; Ozturk et al., 2003; Shaheen and El-Fattah, 1995). Interestingly, a protective effect of $\mathrm{Zinc}(\mathrm{Zn})$ has been reported in vitro against the cellular toxicity due to cadmium, Zinc protection is probably due to an action on oxidative stress and apoptosis.

\section{CONCLUSION}

It can be concluded that, camel's milk has a renoprotective potential against cisplatin-induced oxidative stress and renal dysfunction in mice. Hence, it cane be used as therapeutic adjuvant in cisplatin nephrotoxicity.

\section{REFERENCES}

Agrawal, R.P., S.C. Swami, R. Beniwal, D.K. Kochar and R.P. Kothari, 2002. Effect of camel milk on glycemic control, risk factors and diabetes quality of life in type-1 diabetes: A randomized prospective controlled study. Int. J. Diabetes Dev. Count., 22: 70-74. http://www.vitalcamelmilk.com/pdf/agrawal-2003.pdf

Al-Hashem, F., 2009. Camel's milk protects against aluminum chloride-induced toxicity in the liver and kidney of white albino rats. Am. J. Biochem. Biotechnol., 5: 98-109. http://www.scipub.org/fulltext/ajbb/ajbb5398-108.pdf

Aydogan, S., H. Yapislar, S. Artis and B. Aydogan, 2008. Impaired erythrocytes deformability in $\mathrm{H}_{2} \mathrm{O}_{2}-$ induced oxidative stress: Protective effect of Lcarnosine. Clin. Hemorheol. Microcirc., 39: 93-98. http://iospress.metapress.com/content/d3n786182j3 276p5/
Baker, H. and O. Frank, 1968. Determination of Vitamin E. 6th Edn., Worley's Practical Clinical Biochemistry, pp: 901-903.

Barbagallo, M., 1999. Effects of vitamin E and glutathione on glucose metabolism: Role of magnesium. Hypertension, 34: 1002-1006. PMID: 10523398

Cai, Y.Q., H. Teranishi, K. Aoshima, T. Katoh and Y. Arai et al., 2001. Development of the fluorometric ELISA method for determination of alpha (1) microglobulinuria in cadmium-polluted area in Japan. Int. Arch. Occup. Environ. Health, 7: 514-518. PMID: 11697455

Cepeda, V., M.A. Fuertes, J. Castilla, C. Alonso and C. Quevedo et al., 2007. c. Anticancer Agents Med. Chem., 7: 3-18. PMID: 17266502

Frederickson, C.J., 1989. Neurobiology of zinc and zinc containing neurons. Int. Rev. Neurobiol., 31: 145-238. PMID: 2689380

Huang, Q., R.T. Dunn, S. Jayadev, O. DiSorbo and F.D. Pack et al., 2001. Assessment of cisplatininduced nephrotoxocity by microarray technology. Toxicol. Sci., 63: 196-207. PMID: 11568363

Jones, P.S. Savory, P. Barratt, A.R. Bell, T.J. Gray and N.A. Jenkins et al., 1995. Chromosomal localisation, inducibility, tissue-specific expression and strain differences in three murine peroxisome proliferator-activatedreceptorgenes. Eur. J. Biochem., 233: 219-226. PMID: 7588749

Joy, J. and K. Nair, 2008. Amelioration of cisplatin induced nephrotoxicity in Swiss albino mice by Rubia cordifolia extract. J. Cancer Res. Therapeut., 4: 111-115. PMID: 18923202

Kyaw, A., 1978. A simple colorimetric method for ascorbic acid determination. Clin. Chim. Acta, 86: 153-157. PMID: 657538

Lalila, A., H. Ola, A. Hossam, M. Mohamed and A. Sayed, 2001. Effect of cremophor-EL on cisplatin-induced organ toxicity in normal rat. $\mathrm{J}$. Egypt. Nat. Cancer Inst., 13: 139-145. http://www.nci.edu.eg/Journal/01_06_08.pdf

Mal, G., D.S. Sena, V.K. Jain and M.S. Sahani, 2001. Therapeutic utility of camel milk as nutritional supplement in chronic pulmonary tuberculosis. Livestock Int., 2001: 4-8.

Martin, H., L. Richert and A. Berthelot, 2003. Magnesium deficiency induces apoptosis in primary cultures of rat hepatocytes. Am. Soc. Nut., 133: 2505-2511. PMID: 12888628

Noori, S. and T. Mahboobc, 2010. Antioxidant effect of carnosine pretreatment on cisplatin-induced renal oxidative stress in rats. Ind. J. Clin. Biochem., 25: 86-91. DOI: 10.1007/s12291-010-0018-X 
Ozdemir, G. and F. Inanc, 2005. Zinc may protect remote ocular injury caused by intestinal ischemia reperfusion in rats. Tohoku J. Exp. Med., 206: 247-251. PMID: 15942153

Ozturk, A., A.K. Baltaci, R. Mogulkoc, E. Oztekin and A. Sivrikaya et al., 2003. Effects of zinc deficiency and supplementation on malondialdehyde and glutathione levels in blood and tissue of rats performing swimming exercise. Biol. Trace Elem. Res., 96: 227-236. PMID: 14716102

Santos, N.A., C.S. Bezerra, N.M. Martins, C. Curti and M.L. Bianchi et al., 2008. Hydroxyl radical scavenger ameliorates cisplatin-induced nephrotoxicity by preventing oxidative stress, redox state unbalance, impairment of energetic metabolism and apoptosis in rat kidney mitochondria. Cancer Chemother. Pharmacol., 61: 145-155. DOI: 10.1007/s00280-007-0459-y

Shaheen, A.A. and A.A. El-Fattah, 1995. Effect of dietary zinc on lipid peroxidation, glutathione, protein levels and superoxide dismutase activity in rat tissues. Int. J. Biochem. Cell. Biol., 27: 89-95. PMID: 7757885

Sato, M. and I. Bremner, 1993. Oxygen free radicals and metallothionein. Free Radic. Biol. Med., 14: 325-327. PMID: 8458590

Silva, C.R., L.M. Greggi Antunes and M. Bianchi, 2001. Antioxidant action of bixin against cisplatininduced chromosome aberrations and lipid peroxidation in rats. Pharmacol. Res., 43: 561-566. PMID: 11419966
Somani, S.M., K. Husain, C. Whitworth, G.L. Trammel and M. Malafa et al., 2000. Dose-dependent protection by lipoic acid against cisplatin induced nephrotoxicity in rats: Antioxidant defense system. Pharmacol. Toxicol., 86: 234-241. PMID: 10862506

Tsuji, T., A. Kato, H. Yasuda, T. Miyaji and J. Luo et al., 2009. The dimethylthiourea-induced attenuation of cisplatin nephrotoxicity is associated with the augmented induction of heat shock proteins. Toxicol. Applied Pharmacol., 234: 202-208. PMID: 18992762

Virginia, M., M.B. Smith, M.J. Brauner and M.P. Majerus, 1971. Glutathione synthesis in human erythrocytes. J. Clin. Invest., 50: 507-513. http://www.jci.org/articles/view/106652

Xu, F., T.F. Fok, E. Yung, J.A. Yin and T.O. KF, 2000. Antioxidant enzyme activities and antioxidant enzyme gene expression in hyperoxia-induced lung injury in premature rat. HK J. Paediatr., 5: 3-7. http://hkjpaed.org/details.asp?id=238\&show $=1234$

Yao, X., K. Ichpisal, N, Kurtzman and K. Nugent, 2007. Cisplatin nephrotoxicity: A review. Am. J. Med. Sci., 334: 115-124. PMID: 17700201 